\title{
Psychometric properties of the Indonesian version of the Depression Anxiety Stress Scale: Factor structure, reliability, gender, and age measurement invariance
}

\author{
Darmawan Muttaqin, ${ }^{1 *}$ Serena Ripa ${ }^{2}$ \\ ${ }^{1}$ Faculty of Psychology, Universitas Surabaya, Surabaya - Indonesia, ${ }^{2}$ Centro la Famiglia Onlus, Naples - Italy
}

\begin{abstract}
Measuring instruments that have satisfactory psychometric properties are needed to improve mental health research and services, especially in the effort to measure, identify, and monitor psychological problems experienced by individuals. The purpose of this study is to examine the psychometric properties of the Indonesian version of the Depression Anxiety Stress Scale (DASS). The study involved 1922 participants aged 16-26 in Surabaya, Indonesia. Data collection was made using the convenience sampling method. Testing of the factor structure, reliability, and measurement invariance of the Indonesian version of the DASS was conducted using confirmatory factor analysis, composite reliability, and multi-group analysis. It was found that the bifactor model consisting of specific factors (depression, anxiety, and stress) and general factors (psychological distress) was the best factor structure of the Indonesian version of the DASS (GFI = .954, CFI = .956, RMSEA = .049). In addition, this version has satisfactory composite reliability $(.806-917)$ and gender measurement is invariant. The findings indicate that the Indonesian version of the DASS was a valid and reliable measurement tool to measure and compare depression, anxiety, stress, and psychological distress between genders in the Indonesian sample.
\end{abstract}

Keywords: DASS; factor structure; measurement invariance; psychological distress; reliability

\begin{abstract}
Abstrak: Alat ukur yang memiliki properti psikometri yang memuaskan diperlukan untuk meningkatkan penelitian dan pelayanan kesehatan mental. Khususnya sebagai upaya untuk mengukur, mengidentifikasi, dan memantau permasalahan psikologis yang dialami oleh individu. Tujuan penelitian ini adalah menguji properti psikometri dari Depression Anxiety Stress Scale (DASS) versi Indonesia. Penelitian ini melibatkan 1922 partisipan berusia 16-26 tahun yang sedang berada di Surabaya, Indonesia. Pengambilan data dilakukan dengan metode convenience sampling. Pengujian struktur faktor, reliabilitas, dan invariansi pengukuran dari DASS versi Indonesia dilakukan dengan menggunakan analisis konfirmatori faktor, reliabilitas komposit, dan analisis multi-kelompok. Penelitian ini menemukan bahwa model bifaktor yang terdiri dari faktor spesifik (depresi, kecemasan, dan stres) dan faktor umum (distress psikologis) merupakan struktur faktor terbaik dari DASS versi Indonesia $(\mathrm{GFI}=0,954$. CFI = 0,956, RMSEA $=0,049$ ). Selain itu, DASS versi Indonesia memiliki reliabilitas komposit yang memuaskan $(0,806-0,917)$ dan terdapat invariansi pengukuran gender. Temuan ini mengindikasikan bahwa DASS versi Indonesia merupakan alat ukur yang valid dan reliabel untuk mengukur dan membandingkan depresi, kecemasan, stres, dan distres psikologis antar gender pada sampel Indonesia.
\end{abstract}

Kata Kunci: DASS; distres psikologis; invariansi pengukuran; reliabilitas; struktur faktor

\footnotetext{
*Corresponding Author: Darmawan Muttaqin (darmawan.muttaqin@staff.ubaya.ac.id), Faculty of Psychology, Universitas Surabaya, Jl. Raya Kalirungkut, Surabaya 60293-Indonesia.
} 


\section{Introduction}

Depression, anxiety, and stress have become a major concern for mental health practitioners and researchers worldwide. However, they are psychological problems often handled by clinical psychologists (Borkovec et al., 2006) and not all sufferers receive adequate treatment (Downs et al., 2013; Kataoka et al., 2002). Providing and using measurement instruments with satisfactory psychometric properties have been a major challenge for mental health practitioners and researchers. Therefore, in order to improve research and services in the mental health field, a measurement instrument is needed for measuring, identifying, and monitoring psychological problems experienced by individuals (Henkel, 2003; Liptzin, 2009; Ronk et al., 2013).

The Depression Anxiety Stress Scale (DASS) is a tool for measuring depression, anxiety, and stress (Lovibond \& Lovibond, 1995). Information research into its psychometric properties was first conducted using exploratory and confirmatory factor analysis methods, and it was found that the DASS had a three-factor structure, namely depression, anxiety, and stress. Furthermore, a relatively moderate positive correlation was found between the subscales for the three factors. The results of convergent validity testing by correlating the anxiety subscale with the Beck Anxiety Inventory produced a correlation coefficient of 0.81 , while the correlation between the depression subscale and the Beck Depression Inventory produced a correlation coefficient of 0.74. Research conducted by Lovibond and Lovibond (1995) found that the DASS had good psychometric properties for measuring depression, anxiety, and stress. Furthermore, Lovibond and Lovibond explain the differences in the measurement objectives of each DASS subscale. First, the depression subscale measures situations in which individuals experience loss of self-esteem and feel unable to achieve their expected life goals. Second, the anxiety subscale measures the fear response when individuals face situations that give rise to anxiety. Finally, the stress subscale measures feelings of annoyance or frustration when individuals experience continuous tension beyond their tolerance.

Between 2000 and 2020, the DASS was tested for its psychometric properties in various countries around the world. For example, in Europe, research was conducted in Italy (Bottesi et al., 2015; Severino \& Haynes, 2010); Sweden (Alfonsson et al., 2017); Spain (Bados et al., 2005); England (Crawford \& Henry, 2003; Henry \& Crawford, 2005; Page et al., 2007); and Portugal (Apóstolo et al., 2006; Xavier et al., 2017). In the Americas, studies on the psychometric properties of DASS included participants from the United States (Daza et al., 2002; Kia-Keating et al., 2018; Moore et al., 2017) and from Brazil (Patias et al., 2016; Vignola \& Tucci, 2014). Furthermore, other studies have examined these properties in South Africa (Coker et al., 2018; Dreyer et al., 2019); Australia (Ng et al., 2007; Randall et al., 2017; Tully et al., 2009), and New Zealand (Medvedev et al., 2018). In Asia, several versions of the DASS have been examined, including in Turkish (Hekimoglu et al., 2012; Ylldırım et al., 2018); Arabic (Ali et al., 2017); Nepalese (Tonsing, 2014); Persian (Asghari et al., 2008); Korean (Lee et al., 2019); Vietnamese (Le et al., 2017; Tran et al., 2013); and Malaysian (Musa et al., 2007) versions, and their psychometric properties tested.

In general, the DASS has been used to measure depression, anxiety, and stress in both 
clinical samples (Almhdawi et al., 2020; Joplin \& Vrklevski, 2017; Wang et al., 2017) and the general population (Conley et al., 2020; Negi et al., 2019; Schnapp et al., 2020). This is supported by the psychometric property information of DASS used in clinical samples (Le et al., 2017; Musa et al., 2007; Yohannes et al., 2019) and the general population (Medvedev et al., 2018; Severino \& Haynes, 2010; Sinclair et al., 2012). Regarding the clinical samples, psychometric property testing of the DASS has been made by studying psychiatric patients (Apóstolo et al., 2006; Ng et al., 2007; Vignola \& Tucci, 2014); patients with depression (Clara, Cox, \& Enns, 2001; Lee et al., 2019); and in terms of mood (Page et al., 2007; Yıldırım et al., 2018), anxiety and mental disorders (Hekimoglu et al., 2012); and brain injury (Randall et al., 2017). Participants such as adolescents (Mellor et al., 2015; Moore et al., 2017); college students (Lee, 2019; Norton, 2007; Osman et al., 2012; Patias et al., 2016); and workers (Dreyer et al., 2019) are often included in studies that examine the psychometric properties of the DASS.

The majority of the studies examining the factor structure of the DASS have found that the three-factor correlation model consisting of depression, anxiety, and stress is the best factor structure for it (Asghari et al., 2008; Bados et al., 2005; Clara et al., 2001; Crawford \& Henry, 2003; Daza et al., 2002; Dreyer et al., 2019; Lee et al., 2019; Mellor et al., 2015; Musa et al., 2007; Norton, 2007; Page et al., 2007; Xavier et al., 2017; Ylldırım et al., 2018). This is consistent with the conceptualization of the DASS to measure these three factors (Lovibond \& Lovibond, 1995). However, several studies have suggested that the DASS could be used to measure psychological distress. This is in line with recent findings which show that a bifactor model consisting of a general factor (psychological distress) and three specific factors (depression, anxiety, and stress) is the best structure for the DASS (Henry \& Crawford, 2005; Le et al., 2017; Moore et al., 2017; Randall et al., 2017). This is supported by other studies which have found that such a model has better accuracy than the three-factor correlation (Alfonsson et al., 2017; Bottesi et al., 2015; Kia-Keating et al., 2018; Osman et al., 2012). However, these studies found that both models had a satisfactory model fit when constructed to test the factor structure of the DASS.

The DASS psychometric property information reported in several previous studies is not only related to the factor structure but also to the reliability. The studies have reported that it has satisfactory internal consistency (0.74 to 0.92) with regard to the depression, anxiety, and stress subscales (Bados et al., 2005; Coker et al., 2018; Musa et al., 2007; Norton, 2007; Tonsing, 2014) as well as for the entire scale measuring psychological distress (Bottesi et al., 2015; Osman et al., 2012; Tran et al., 2013). Apart from the factor structure and reliability, previous research also found that there was national DASS measurement invariance. Furthermore, such invariance was found in a research on Australia, Chile, China, and Malaysia (Mellor et al., 2015); on six Asian countries, Malaysia, Indonesia, Singapore, Sri Lanka, Taiwan, Thailand (Oei et al., 2013), and on eight other countries, namely Brazil, Canada, Hong Kong, Romania, Taiwan, Turkey, UAE, and the United States (Zanon et al., 2020). The findings regarding the national measurement invariance of the DASS indicate that it does not have any potential bias and could be used to compare depression, anxiety, stress, and psychological distress across nations. 
The DASS has in fact been adapted for Indonesian use by Muttaqin, Yunanto, Fitria, Ramadhanty, and Lempang (2020). However, information regarding the psychometric properties of the Indonesian version is still limited to the factor structure. Muttaqin et al. (2020) examined this structure by compiling a threefactor correlation model, finding that the model had a satisfactory fit, with GFI, CFI and RMSEA coefficients of $0.978,0.988$, and 0.053 respectively. However, the model was prepared using the item parceling method, which could cause difficulties in detecting any inaccuracy in the measurement model (Bandalos, 2002; Little et al., 2002). Therefore, the drawbacks of using this method encouraged us to re-examine the factor structure of the DASS without using parceling items.

In order to complement the limited psychometric property information on the Indonesian version of the DASS, researchers have been encouraged to conduct tests on its reliability and measurement invariance. Measurement invariance testing has been performed to check the potential for bias between groups due to the inaccuracy of the items used in measuring a construct in a particular group (Chen, 2008; Cheung \& Rensvold, 2002). Potential bias, such as gender or age differences, could also threaten the accuracy of the DASS. The measurement invariance testing has been based on configural invariance (the number of factors and item composition being equivalent between groups); metric invariance (the factor load on each item being equivalent between groups); and scalar invariance (the factor load and intercept on each item being equivalent between groups). In addition, testing has been based on covariance invariance (the covariance among latent factors being equivalent between groups) (B. M. Byrne \& van de Vijver, 2010; van de Schoot et al., 2012; Vandenberg \& Lance, 2000).

In general, this study aims to examine the psychometric properties of the Indonesian DASS, with three objectives. First, it aims to examine its factor structure; second, to test its reliability; and finally, to examine the invariance of the gender and age measurements.

\section{Method}

\section{Participants}

Using a non-probabilistic convenience sample, 1922 participants were recruited through an online survey from Surabaya city. They were aged between 16 and $26(\mathrm{M}=20.835, \mathrm{SD}=$ 2.284), and comprised 948 (49.3\%) adolescents aged from 16 to $20(\mathrm{M}=18.936, \mathrm{SD}=0.870)$ and 974 (50.7\%) adults aged between 21 and $26(\mathrm{M}=$ $22.684, \mathrm{SD}=1.622$ ). From the gender perspective, the participants consisted of 953 (49.6\%) males and 969 (50.4\%) females. They were 36 (1.9\%) diploma program students, 1262 (65.7\%) undergraduates, 153 (8.0\%) master's program students, and 408 (21.2\%) individuals who were working, with the remaining 63 (3.3\%) providing other answers. The majority of the participants (77.9\%) had grown up in big cities, while the rest lived in small cities (19.3\%) and villages (2.8\%).

\section{Measures}

The Depression Anxiety Stress Scale by Lovibond and Lovibond (1995) was used to measure depression (seven items, such as "I felt I wasn't worth much as a person"); anxiety (seven items, such as "I felt I was close to panic"); and stress (seven items, for example, "I found it difficult to relax"). The DASS used four response options ranging from 0 (never) to 3 (often). The 
DASS used in this study was the Indonesian version adapted by Muttaqin et al. (2020).

\section{Procedures}

Data were collected from 2018/09/02 to 2020/04/04. The participants were contacted directly or through an advertising campaign on social media (WhatsApp, LINE, and Instagram): Before they became involved in the study, they were asked to read and complete the research informed consent form stating their willingness or unwillingness to be involved in the research. Initially, 1934 individuals agreed to participate; however, 12 incomplete questionnaires were deleted, so a definitive sample of 1922 participants were obtained.
Confirmatory factor analysis through the IBM SPSS AMOS 21 program with maximum likelihood estimation (Arbuckle, 2012) was used to evaluate the factor structure of the Indonesian DASS version. Based on results from previous research, the version was evaluated for its factor structure using two models, namely three-factor correlation arranged by including 21 items consisting of seven depression, anxiety, and stress items. The bifactors were arranged as in the three-factor correlation model, but with an additional common factor, namely psychological distress (Figure 1). Second, model fit indexes, namely the Goodness of Fit Index (GFI), Comparative Fit Index (CFI), and Root Mean Square Error of Approximation (RMSEA), were

Figure 1

Conceptual bifactor model of the Indonesian DASS version

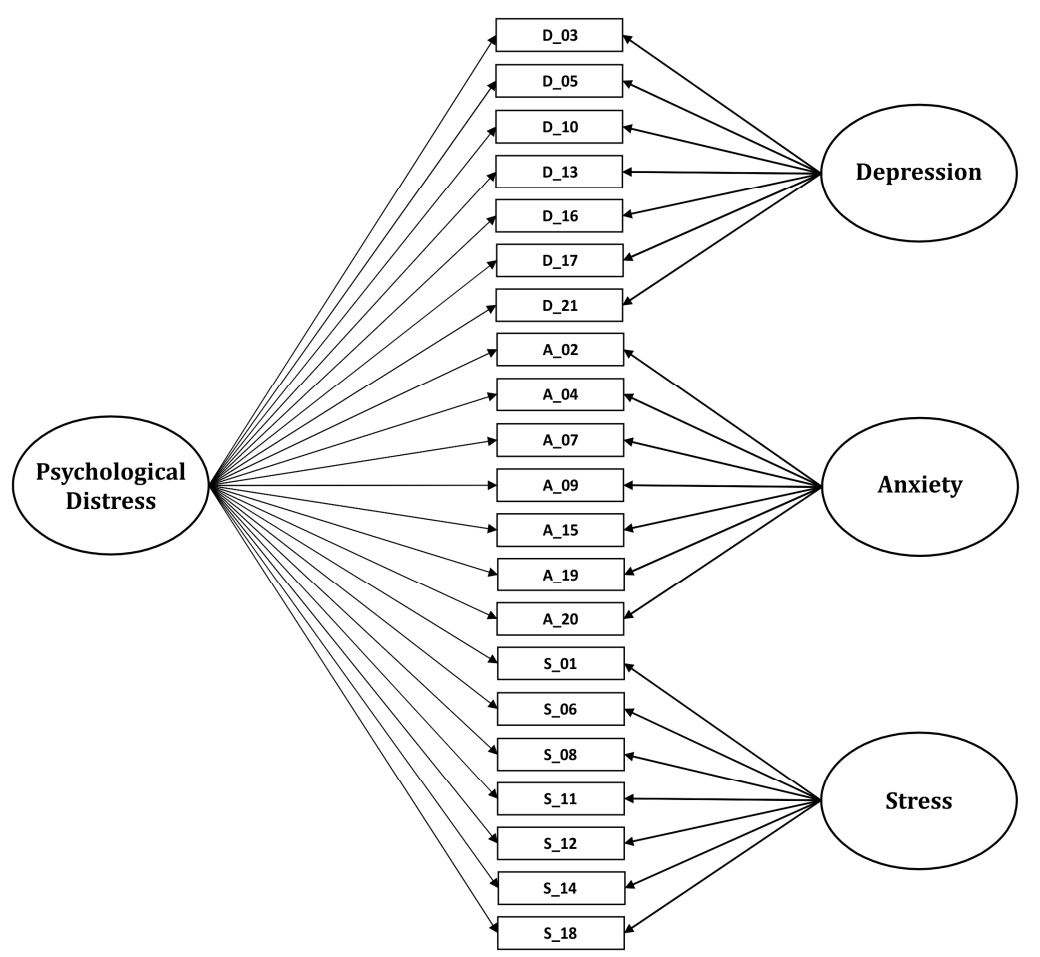


used to evaluate the measurement model of the Indonesian DASS. Such a model is stated to have conformity with the data if its GFI and CFI coefficients are greater than or equal to .90 (Bentler \& Bonett, 1980; Cole, 1987; Kline, 2014) and the RMSEA coefficient is less than .08 (Kline, 2014; Schreiber et al., 2006; van de Schoot et al., 2012) Composite reliability calculations were also used to evaluate the measurement model. Furthermore, when the composite reliability coefficient is greater than .70 , it can be stated that the model has satisfactory internal consistency (Hair et al., 2014). Finally, a multi-group analysis was made to evaluate the measurement invariance of gender and age. The measurement model can be considered to have measurement invariance in gender and age when there is a difference in the CFI and RMSEA coefficients of less than .010 and .015 respectively (Chen, 2007).

\section{Results}

The results of the confirmatory factor analysis (Table 1) show that the measurement model of the Indonesian DASS version, which was compiled from the three-factor correlation and bifactor models, had a satisfactory fit model.
This is because the two models had GFI and CFI coefficients greater than .90, and a RMSEA coefficient of less than .08. However, the bifactor model was a better fit than the three-factor one, and also when it was tested on males, females, adolescents, and adults.

The correlation between the subscales (Table 2) is highly positive. Furthermore, the depression subscale has a positive relationship with the anxiety subscale $(\mathrm{r}=.782, \mathrm{p}<.001)$ and the stress subscale ( $\mathrm{r}=.791, \mathrm{p}<.001)$. In addition, the anxiety subscale had a positive relationship with the stress subscale $(r=.981, \mathrm{p}<.001)$. The Indonesian DASS has a satisfactory composite reliability of $.872, .806, .816$, and .917 for the depression, anxiety, stress subscales, and psychological distress subscale respectively.

The results of the multi-group analysis show that the three-factor correlation and bifactor models of the Indonesian DASS version have gender measurement invariance (see Table 3). This is because both models fulfil the CFI coefficient difference of less than -.010 and the RMSEA coefficient difference of less than .015 , based on metric, scalar, and covariance invariance.

Table 1

Model Fit Indices of the Indonesian DASS Version

\begin{tabular}{|c|c|c|c|c|}
\hline & \multicolumn{4}{|c|}{ Model fit indices } \\
\hline & $\chi^{2} / \mathrm{df}$ & GFI & CFI & RMSEA \\
\hline \multicolumn{5}{|l|}{ Three-factor correlation model } \\
\hline Total sample $(\mathrm{n}=1922)$ & 8.800 & .918 & .917 & .064 \\
\hline Males $(n=953)$ & 4.790 & .913 & .918 & .063 \\
\hline Females $(\mathrm{n}=969)$ & 5.628 & .899 & .903 & .069 \\
\hline Adolescents $(n=948)$ & 5.145 & .907 & .901 & .066 \\
\hline Adults $(\mathrm{n}=974)$ & 4.802 & .913 & .921 & .063 \\
\hline \multicolumn{5}{|l|}{ Bifactor model } \\
\hline Total sample $(\mathrm{n}=1922)$ & 5.567 & .954 & .956 & .049 \\
\hline Males $(\mathrm{n}=953)$ & 3.370 & .938 & .947 & .054 \\
\hline Females $(n=969)$ & 3.473 & .944 & .953 & .051 \\
\hline Adolescents $(n=948)$ & 3.448 & .944 & .947 & .051 \\
\hline Adults $(\mathrm{n}=974)$ & 3.324 & .947 & .956 & .049 \\
\hline
\end{tabular}


Table 2

Correlation and Composite Reliability of the Indonesian DASS

\begin{tabular}{lccc}
\hline & Depression & Anxiety & Stress \\
\hline Depression & $(.872)$ & & \\
Anxiety & $.782^{*}$ & $(.806)$ & \\
Stress & $.791^{*}$ & $.981^{*}$ & $(.816)$ \\
\hline
\end{tabular}

${ }^{*} \mathrm{p}<0.001$

Figure 2

Factor Structure of the Three-factor Correlation Model of the Indonesian DASS

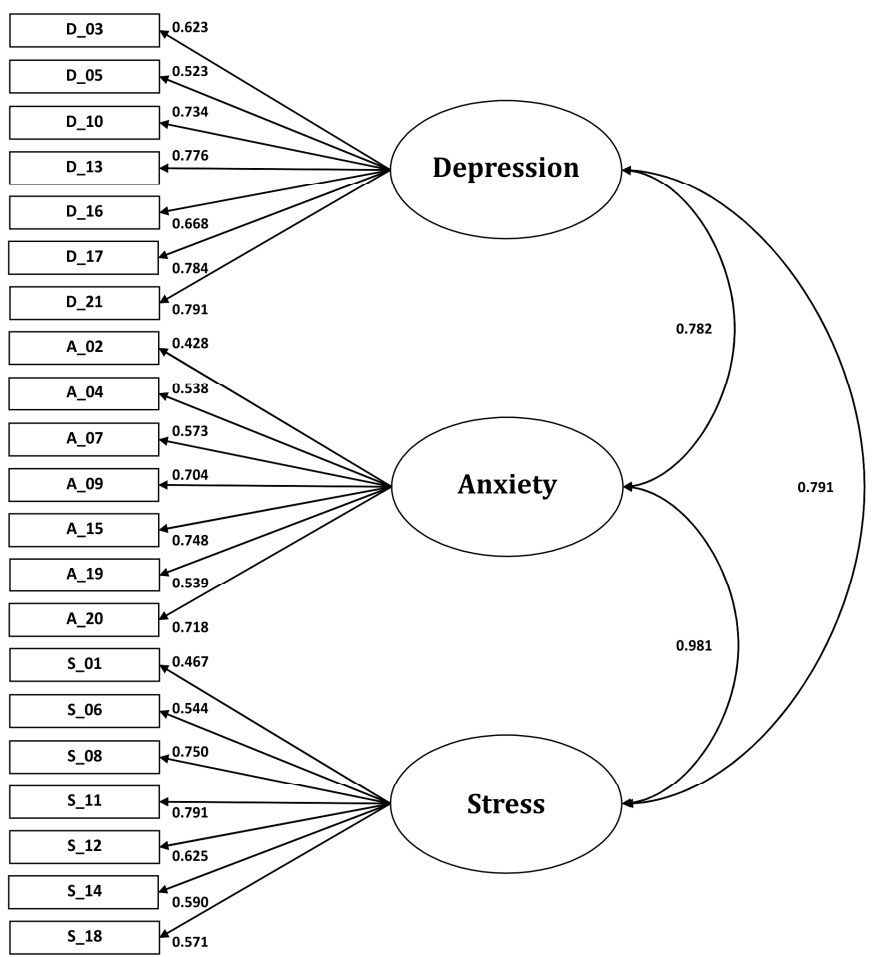

However, both models only fulfilled the metric invariance in the age measurement invariance test. This was because the CFI coefficient difference was greater than - .010 and the RMSEA coefficient difference was less than .015 on the scalar invariance and covariance. However, the bifactor model had a better fit in terms of configural, metric, and scalar invariances than the three-factor correlation. 
Table 3

Gender and Age Measurement Invariance of the Indonesian DASS

\begin{tabular}{|c|c|c|c|c|c|c|}
\hline & \multicolumn{4}{|c|}{ Model fit indices } & \multicolumn{2}{|c|}{ Model comparison } \\
\hline & $\chi^{2}$ & df & CFI & RMSEA & $\Delta \mathrm{CFI}$ & $\triangle$ RMSEA \\
\hline \multicolumn{7}{|l|}{ Three-factor correlation model } \\
\hline \multicolumn{7}{|l|}{ Gender measurement invariance } \\
\hline 1. Configural invariance & 1937.715 & 382 & .910 & .046 & & \\
\hline 2. Metric invariance (compared to 1 ) & 1957.060 & 393 & .910 & .045 & .000 & -.001 \\
\hline 3. Scalar invariance (compared to 2) & 2056.172 & 414 & .906 & .045 & -.004 & .000 \\
\hline 4. Covariance invariance (compared to 2 ) & 2068.246 & 417 & .905 & .045 & -.005 & .000 \\
\hline \multicolumn{7}{|l|}{ Age measurement invariance } \\
\hline 1. Configural invariance & 1850.117 & 372 & .912 & .045 & & \\
\hline 2. Metric invariance (compared to 1 ) & 1906.055 & 393 & .910 & .045 & -.002 & .000 \\
\hline 3. Scalar invariance (compared to 2) & 2267.035 & 414 & .889 & .048 & -.021 & .003 \\
\hline 4. Covariance invariance (compared to 2) & 2307.787 & 417 & .887 & .049 & -.023 & .004 \\
\hline \multicolumn{7}{|l|}{ Bifactor model } \\
\hline \multicolumn{7}{|l|}{ Gender measurement invariance } \\
\hline 1. Configural invariance & 1204.699 & 336 & .950 & .037 & & \\
\hline 2. Metric invariance (compared to 1 ) & 1264.977 & 378 & .949 & .035 & -.001 & -.002 \\
\hline 3. Scalar invariance (compared to 2) & 1365.411 & 399 & .945 & .036 & -.004 & .001 \\
\hline \multicolumn{7}{|l|}{ Age measurement invariance } \\
\hline 1. Configural invariance & 1137.702 & 336 & .952 & .035 & & \\
\hline 2. Metric invariance (compared to 1 ) & 1270.222 & 378 & .947 & .035 & -.005 & .000 \\
\hline 3. Scalar invariance (compared to 2) & 1627.106 & 399 & .927 & .040 & -.020 & .005 \\
\hline
\end{tabular}

\section{Discussion}

The purpose of this study was to examine the psychometric properties of the Indonesian DASS version in the form of factor structure, reliability, gender, and age invariance measurements. It was found that the three-factor correlation and bifactor models had a satisfactory fit when used to test the DASS factor structure. The bifactor model was the better of the two because it had better accuracy when tested on the total sample and a separate sample of men, women, adolescents, and adults. It was also found that the Indonesian DASS had satisfactory internal consistency and an invariance in gender measurements. However, the study did not find any invariance in age measurements based on scalar invariance and covariance.

The results related to the bifactor model showed it was a better fit than the three-factor correlation one, although both models were found to have a satisfactory model fit. These findings are similar to those of previous studies (Alfonsson et al., 2017; Bottesi et al., 2015; Kia-Keating et al., 2018; Osman et al., 2012). However, this is in contrast to the majority of previous studies, which found the best factor structure for the DASS in the form of a three-factor correlation model (Asghari et al., 2008; Bados et al., 2005; Clara et al., 2001; Crawford \& Henry, 2003; Daza et al., 2002; Dreyer et al., 2019; Lee et al., 2019; Mellor et al., 2015; Musa et al., 2007; Norton, 2007; Page et al., 2007; Xavier et al., 2017; Yıldırım et al., 2018). This is not surprising, as these studies did not include the bifactor model as an alternative for the DASS. Moreover, when some researchers attempted to compare the models, they found that only the bifactor model had a satisfactory fit, while the three-factor correlation model did not fit the data 
(Henry \& Crawford, 2005; Le et al., 2017; Moore et al., 2017; Randall et al., 2017).

The findings showing the bifactor model to be the best structure for the Indonesian DASS version indicate that the DASS could be used to measure depression, anxiety, stress, and psychological distress. This is because the bifactor model has been considered to be an alternative to the hierarchical model as it can test specific and general factors at the same time (Chen et al., 2012; Zhang et al., 2020). Furthermore, Reise (2012) states that bifactor model testing could be used to identify the ability of items to measure general and specific factors that are in accordance with their construct (Reise, 2012). Therefore, the Indonesian DASS could be an alternative measuring instrument for psychological distress, which is considered a common characteristic of psychopathological symptoms and mood disorders (Bottesi et al., 2015).

This study found a high positive correlation between the Indonesian DASS subscales. This is similar to previous studies, which also found that there was a correlation coefficient greater than 0.70 between the subscales (Apóstolo et al., 2006; Crawford \& Henry, 2003; Daza et al., 2002; Oei et al., 2013; Sinclair et al., 2012; Tonsing, 2014). Furthermore, other studies have also found relatively moderate correlation coefficients between the DASS subscales (Asghari et al., 2008; Bados et al., 2005; Lee, 2019; Musa et al., 2007). The existence of a positive correlation between the subscales is in accordance with the conceptualization of the DASS, based on the fact that depression, anxiety, and stress are positively related to each other (Lovibond \& Lovibond, 1995).
It was found that the Indonesian DASS version had satisfactory internal consistency. This is because each subscale had composite reliability greater than 0.80 . Moreover, a composite reliability coefficient greater than .90 was found for the total score of the DASS which measures psychological distress. A measurement model could be considered to have good internal consistency if it fulfills the requirement of a minimum composite reliability coefficient of greater than .70 (Hair et al., 2014). This is similar to previous studies, which have also found that the DASS has a reliability coefficient greater than 0.80 when used for measuring depression, anxiety, and stress (Apóstolo et al., 2006; Asghari et al., 2008; Crawford \& Henry, 2003; Daza et al., 2002; Lee, 2019; Patias et al., 2016; Sinclair et al,, 2012; Vignola \& Tucci, 2014; Xavier et al., 2017; Yıldırım et al., 2018), and a reliability coefficient greater than 0.90 when used for measuring psychological distress (Henry \& Crawford, 2005; Kia-Keating et al., 2018; Le et al., 2017; Page et al., 2007; Randall et al., 2017; Tully et al., 2009).

No studies have previously examined the invariance of gender and age measurement in the DASS. However, this study found an invariance of gender measurements based on configuration, metric, and scalar invariance in the Indonesian DASS. This indicates that there is no difference in the number of factors and the composition of items between the male and female samples (Chen, 2008). Furthermore, this study also found that the Indonesian DASS version only fulfilled metric invariance in the age measurement invariance test. The absence of scalar invariance in this test indicates the differences in response between the adolescent and adult samples. This difference could be due to the fact that the age 
groups had different understandings of the same item (Blankson \& McArdle, 2015; Horn \& Mcardle, 1992; Millsap \& Kwok, 2004; Millsap \& Olivera-Aguilar, 2012). Furthermore, it also indicates that the Indonesian DASS could only be used to compare depression, anxiety, stress, and psychological distress between genders.

In general, this study contributes to the psychometric properties of the Indonesian DASS version. Therefore, it could be used precisely to measure depression, anxiety, stress, and psychological distress in the Indonesian sample, especially in the general population. However, there are several limitations to this study. First, it did not test the convergent validity of the Indonesian DASS. Information on such validity could be used to evaluate the fit of the DASS measurement results. This is because through convergent validity testing the validated results of a measuring instrument would be tested for correlation with other instruments that have the same construct (Bandalos, 2018; Carlson \& Herdman, 2012; Furr, 2011). Second, this study only involved participants from the general population. Therefore, the fit of this version for depression, anxiety, stress, and psychological distress in a clinical sample is still unclear.

In order to improve the fit of the measurement results from the Indonesian DASS, convergent validity needs to be tested. This could be done by using other measuring instruments that have the same construct. For example, the Beck Depression Inventory-II (Beck et al., 1996), the Patient Health Questionnaire-9 (Kroenke, Spitzer, \& Williams, 2001), or the Center for Epidemiologic Studies Depression Scale-Revised (Radloff, 1977) could be used to measure depression. In addition, the Beck Anxiety Inventory (Beck, Epstein, Brown, \& Steer, 1988), Generalized Anxiety Disorder (Spitzer et al., 2006), the Mood and Anxiety Symptom Questionnaire-90 (Watson et al., 1995), or the State-Trait Anxiety Inventory Y-II (Spielberger et al., 1970) could also be used to measure anxiety. Finally, the Perceived Stress Questionnaire (Fliege et al., 2005), Perceived Stress Scale (Cohen \& Herbert, 1996), or Adolescent Stress Questionnaire (D. G. Byrne et al., 2007) could be used to measure stress. Moreover, further tests need to be conducted on the psychometric properties of the Indonesian DASS using clinical samples.

\section{Conclusion}

Based on the results, it is concluded that the Indonesian DASS is a valid and reliable measuring instrument for depression, anxiety, stress, and psychological distress in the Indonesian sample, especially in the general population. This is because it has the best factor structure in the form of three specific factors (depression, anxiety, and stress) and a general factor (psychological distress), and it has very satisfactory composite reliability. Furthermore, it could be used to compare scores for depression, anxiety, stress, and psychological distress in terms of gender.

\section{Conflicts of Interest}

The authors declare that the research was conducted in the absence of any commercial or financial relationships that could be construed as a potential conflict of interest.

\section{Funding}

The author(s) received no financial support for the research of this article.[ 


\section{References}

Alfonsson, S., Wallin, E., \& Maathz, P. (2017). Factor structure and validity of the Depression, Anxiety and Stress Scale-21 in Swedish translation. Journal of Psychiatric and Mental Health Nursing, 24(23), 154-162. https://doi.org/10.1111/jpm.12363

Ali, A. M., Ahmed, A., Sharaf, A., Kawakami, N., Abdeldayem, S. M., \& Green, J. (2017). The Arabic version of the Depression Anxiety Stress Scale-21: Cumulative scaling and discriminant-validation testing. Asian Journal of Psychiatry, 30, 56-58. https://doi.org/10.1016/j.ajp.2017.07.018

Almhdawi, K. A., Alazrai, A., Kanaan, S., Shyyab, A. A., Oteir, A. O., Mansour, Z. M., \& Jaber, H. (2020). Poststroke depression, anxiety, and stress symptoms and their associated factors: A cross-sectional study. Neuropsychological Rehabilitation, 1-14. https://doi.org/10.1080/09602011.2020.1760893

Apóstolo, J. L. A., Mendes, A. C., \& Azeredo, Z. A. (2006). Adaptation to Portuguese of the Depression, Anxiety and Stress Scales (DASS). Revista Latino-Americana de Enfermagem, 14(6), 863-871. https://doi.org/10.1590/S0104-11692006000600006

Arbuckle, J. L. (2012). IBM SPSS Amos 21 users guide. Amos Development Corporation.

Asghari, A., Saed, F., \& Dibajnia, P. (2008). Psychometric properties of the Depression Anxiety Stress Scales-21 (DASS-21) in a non-clinical Iranian sample. International Journal of Psychology, 2(2), 82-102.

Bados, A., Solanas, A., \& Andrés, R. (2005). Psychometric properties of the Spanish version of Depression, Anxiety and Stress Scales (DASS). Psicothema, 17(4), 679-683.

Bandalos, D. L. (2002). The effects of item parceling on goodness-of-fit and parameter estimate bias in structural equation modeling. Structural Equation Modeling: A Multidisciplinary Journal, 9(1), 78-102. https://doi.org/10.1207/S15328007SEM0901_5

Bandalos, D. L. (2018). Measurement theory and applications for the social sciences. The Guilford Press.

Beck, A. T., Epstein, N., Brown, G., \& Steer, R. A. (1988). An inventory for measuring clinical anxiety: Psychometric properties. Journal of Consulting and Clinical Psychology, 56(6), 893-897. https://doi.org/10.1037/0022-006X.56.6.893

Beck, A. T., Steer, R. A., \& Brown, G. K. (1996). Manual for the revised Beck Depression Inventory-II. Psychological Corporation.

Bentler, P. M., \& Bonett, D. G. (1980). Significance tests and goodness of fit in the analysis of covariance structures. Psychological Bulletin, 88(3), 588-606. https://doi.org/10.1037/00332909.88.3.588

Blankson, A. N., \& McArdle, J. J. (2015). Measurement invariance of cognitive abilities across ethnicity, gender, and time among older Americans. The Journals of Gerontology Series B: Psychological Sciences and Social Sciences, 70(3), 386-397. https://doi.org/10.1093/geronb/gbt106

Borkovec, T. D., Echemendia, R. J., Ragusea, S. A., \& Ruiz, M. (2006). The Pennsylvania practice research network and future possibilities for clinically meaningful and scientifically rigorous psychotherapy effectiveness research. Clinical Psychology: Science and Practice, 8(2), 155-167. https://doi.org/10.1093/clipsy.8.2.155

Bottesi, G., Ghisi, M., Altoè, G., Conforti, E., Melli, G., \& Sica, C. (2015). The Italian version of the Depression Anxiety Stress Scales-21: Factor structure and psychometric properties on community and $\begin{array}{llll}\text { clinical samples. } & \text { Comprehensive } & \text { Psychiatry, } & \text { 60, }\end{array}$ https://doi.org/10.1016/j.comppsych.2015.04.005 
Byrne, B. M., \& van de Vijver, F. J. R. (2010). Testing for measurement and structural equivalence in large-scale cross-cultural studies: Addressing the issue of nonequivalence. International Journal of Testing, 10(2), 107-132. https://doi.org/10.1080/15305051003637306

Byrne, D. G., Davenport, S. C., \& Mazanov, J. (2007). Profiles of adolescent stress: The development of the Adolescent Stress Questionnaire (ASQ). Journal of Adolescence, 30(3), 393-416. https://doi.org/10.1016/j.adolescence.2006.04.004

Carlson, K. D., \& Herdman, A. O. (2012). Understanding the impact of convergent validity on research results. Organizational Research Methods, 15(1), 17-32. https://doi.org/10.1177/1094428110392383

Chen, F. F. (2007). Sensitivity of goodness of fit indexes to lack of measurement invariance. Structural Equation Modeling: A Multidisciplinary Journal, 14(3), 464-504. https://doi.org/10.1080/10705510701301834

Chen, F. F. (2008). What happens if we compare chopsticks with forks? The impact of making inappropriate comparisons in cross-cultural research. Journal of Personality and Social Psychology, 95(5), 1005-1018. https://doi.org/10.1037/a0013193

Chen, F. F., Hayes, A., Carver, C. S., Laurenceau, J.-P., \& Zhang, Z. (2012). Modeling general and specific variance in multifaceted constructs: A comparison of the bifactor model to other approaches. Journal of Personality, 80(1), 219-251. https://doi.org/10.1111/j.1467-6494.2011.00739.x

Cheung, G. W., \& Rensvold, R. B. (2002). Evaluating goodness-of-fit indexes for testing measurement invariance. Structural Equation Modeling: A Multidisciplinary Journal, 9(2), 233-255. https://doi.org/10.1207/S15328007SEM0902_5

Clara, I. P., Cox, B. J., \& Enns, M. W. (2001). Confirmatory factor analysis of the Depression-Anxiety-Stress Scales in depressed and anxious patients. Journal of Psychopathology and Behavioral Assessment, 23(1), 61-67. https://doi.org/10.1023/A:1011095624717

Cohen, S., \& Herbert, T. B. (1996). Health psychology: Psychological factors and physical disease from the perspective of human psychoneuroimmunology. Annual Review of Psychology, 47(1), 113142. https://doi.org/10.1146/annurev.psych.47.1.113

Coker, A. O., Coker, O. O., \& Sanni, D. (2018). Psychometric properties of the 21-item Depression Anxiety Stress Scale (DASS-21). African Research Review, 12(2), 135. https://doi.org/10.4314/afrrev.v12i2.13

Cole, D. A. (1987). Utility of confirmatory factor analysis in test validation research. Journal of Consulting and Clinical Psychology, 55(4), 584-594. https://doi.org/10.1037/0022-006X.55.4.584

Conley, C. S., Shapiro, J. B., Huguenel, B. M., \& Kirsch, A. C. (2020). Navigating the college years: Developmental trajectories and gender differences in psychological functioning, cognitiveaffective strategies, and social well-being. Emerging Adulthood, 8(2), 103-117. https://doi.org/10.1177/2167696818791603

Crawford, J. R., \& Henry, J. D. (2003). The Depression Anxiety Stress Scales (DASS): Normative data and latent structure in a large non-clinical sample. British Journal of Clinical Psychology, 42(2), 111131. https://doi.org/10.1348/014466503321903544

Daza, P., Novy, D. M., Stanley, M. A., \& Averill, P. (2002). The Depression Anxiety Stress Scale-21: Spanish translation and validation with a Hispanic sample. Journal of Psychopathology and Behavioral Assessment, 24(3), 195-205. https://doi.org/10.1023/A:1016014818163

Downs, A., Boucher, L. A., Campbell, D. G., \& Dasse, M. (2013). Development and initial validation of the Symptoms and Assets Screening Scale. Journal of American College Health, 61(3), 164-174. https://doi.org/10.1080/07448481.2013.773902 
Psychometric properties of the Indonesian version of the Depression Anxiety Stress Scale ....

Dreyer, Z., Henn, C., \& Hill, C. (2019). Validation of the Depression Anxiety Stress Scale-21 (DASS-21) in a non-clinical sample of South African working adults. Journal of Psychology in Africa, 29(4), 346353. https://doi.org/10.1080/14330237.2019.1647499

Fliege, H., Rose, M., Arck, P., Walter, O. B., Kocalevent, R. D., Weber, C., \& Klapp, B. F. (2005). The Perceived Stress Questionnaire (PSQ) reconsidered: Validation and reference values from different clinical and healthy adult samples. Psychosomatic Medicine, 67(1), 78-88. https://doi.org/10.1097/01.psy.0000151491.80178.78

Furr, R. M. (2011). Scale construction and psychometrics for social and personality psychology. Sage Publications, Inc.

Hair, J. F., Hult, G. T. M., Ringle, C. M., \& Sarstedt, M. (2014). A primer on partial least squares structural equation modeling (PLS-SEM). Sage Publications, Inc.

Hekimoglu, L., Altun, Z., Kaya, E., Bayram, N., \& Bilgel, N. (2012). Psychometric properties of the Turkish version of the 42 item Depression Anxiety Stress Scale (DASS-42) in a clinical sample. International Journal of Psychiatry in Medicine, 44(3), 183-198. https://doi.org/10.2190/PM.44.3.a

Henkel, V. (2003). Identifying depression in primary care: A comparison of different methods in a $\begin{array}{llll}\text { prospective } \quad \text { cohort } & \text { study. } & \text { BMJ, } & \text { 326(7382), }\end{array}$ https://doi.org/10.1136/bmj.326.7382.200

Henry, J. D., \& Crawford, J. R. (2005). The short-form version of the Depression Anxiety Stress Scales (DASS-21): Construct validity and normative data in a large non-clinical sample. British Journal of Clinical Psychology, 44(2), 227-239. https://doi.org/10.1348/014466505X29657

Horn, J. L., \& Mcardle, J. J. (1992). A practical and theoretical guide to measurement invariance in aging research. Experimental Aging Research, 18(3), 117-144. https://doi.org/10.1080/03610739208253916

Joplin, S., \& Vrklevski, L. P. (2017). Emotional anaesthesia: A cognitive-behavioural treatment of prolonged grief in a client with complex comorbidities-the importance of reintegrating attachment, memory, and self-identity. Bereavement Care, 36(1), 25-32. https://doi.org/10.1080/02682621.2017.1305048

Kataoka, S. H., Zhang, L., \& Wells, K. B. (2002). Unmet need for mental health care among U.S. children: Variation by ethnicity and insurance status. American Journal of Psychiatry, 159(9), 1548-1555. https://doi.org/10.1176/appi.ajp.159.9.1548

Kia-Keating, M., No, U., Moore, S., Furlong, M. J., Liu, S., \& You, S. (2018). Structural validity of the Depression, Anxiety, and Stress Scales-21 adapted for U.S. undergraduates. Emerging Adulthood, 6(6), 434-440. https://doi.org/10.1177/2167696817745407

Kline, R. B. (2014). Principles and practices of structural equation modeling (3rd ed.). American Psychological Association.

Kroenke, K., Spitzer, R. L., \& Williams, J. B. W. (2001). The PHQ-9. Journal of General Internal Medicine, 16, 606-613.

Le, M. T. H., Tran, T. D., Holton, S., Nguyen, H. T., Wolfe, R., \& Fisher, J. (2017). Reliability, convergent validity and factor structure of the DASS-21 in a sample of Vietnamese adolescents. PLOS ONE, 12(7), e0180557. https://doi.org/10.1371/journal.pone.0180557

Lee, D. (2019). The convergent, discriminant, and nomological validity of the Depression Anxiety Stress Scales-21 (DASS-21). Journal of Affective Disorders, 259, 136-142. https://doi.org/10.1016/j.jad.2019.06.036 
Lee, E. H., Moon, S. H., Cho, M. S., Park, E. S., Kim, S. Y., Han, J. S., \& Cheio, J. H. (2019). The 21 -item and $12-$ item versions of the Depression Anxiety Stress Scales: Psychometric evaluation in a Korean population. Asian Nursing Research, 13(1), 30-37. https://doi.org/10.1016/j.anr.2018.11.006

Liptzin, B. (2009). Quality improvement, pay for performance, and "outcomes measurement": What makes sense? Psychiatric Services, 60(1), 108-111. https://doi.org/10.1176/ps.2009.60.1.108

Little, T. D., Cunningham, W. A., Shahar, G., \& Widaman, K. F. (2002). To parcel or not to parcel: Exploring the question, weighing the merits. Structural Equation Modeling: A Multidisciplinary Journal, 9(2), 151-173. https://doi.org/10.1207/S15328007SEM0902_1

Lovibond, P. F., \& Lovibond, S. H. (1995). The structure of negative emotional states: Comparison of the Depression Anxiety Stress Scales (DASS) with the Beck Depression and Anxiety Inventories. Behaviour Research and Therapy, 33(3), 335-343. https://doi.org/10.1016/00057967(94)00075-U

Lovibond, S. H., \& Lovibond, P. F. (1995). Manual for the Depression Anxiety Stress Scales (2nd. Ed.). Psychology Foundation.

Medvedev, O. N., Krägeloh, C. U., Titkova, E. A., \& Siegert, R. J. (2018). Rasch analysis and ordinal-tointerval conversion tables for the Depression, Anxiety and Stress Scale. Journal of Health Psychology, 25(10-11), 1374-1383. https://doi.org/10.1177/1359105318755261

Mellor, D., Vinet, E. V., Xu, X., Hidayah Bt Mamat, N., Richardson, B., \& Román, F. (2015). Factorial invariance of the DASS-21 among adolescents in four countries. European Journal of Psychological Assessment, 31(2), 138-142. https://doi.org/10.1027/1015-5759/a000218

Millsap, R. E., \& Kwok, O.-M. (2004). Evaluating the impact of partial factorial invariance on selection in two populations. Psychological Methods, 9(1), 93-115. https://doi.org/10.1037/1082989X.9.1.93

Millsap, R. E., \& Olivera-Aguilar, M. (2012). Investigating measurement invariance using confirmatory factor analysis. In R. Hoyle (Ed.), Handbook of structural equation modeling (pp. 380-392). The Guilford Press.

Moore, S. A., Dowdy, E., \& Furlong, M. J. (2017). Using the Depression, Anxiety, Stress Scales-21 with U.S. adolescents: An alternate models analysis. Journal of Psychoeducational Assessment, 35(6), 581598. https://doi.org/10.1177/0734282916651537

Musa, R., Fadzil, M. A., \& Zain, Z. (2007). Translation, validation and psychometric properties of Bahasa Malaysia version of the Depression Anxiety and Stress Scales (DASS). ASEAN Journal of Psychiatry, 8(2), 82-89.

Muttaqin, D., Yunanto, T. A. R., Fitria, A. Z. N., Ramadhanty, A. M., \& Lempang, G. F. (2020). Properti psikometri Self-Compassion Scale versi Indonesia: Struktur faktor, reliabilitas, dan validitas kriteria. Persona:Jurnal Psikologi Indonesia, 9(2), 189-208. https://doi.org/10.30996/persona.v9i2.3944

Negi, A. S., Khanna, A., \& Aggarwal, R. (2019). Psychological health, stressors and coping mechanism of engineering students. International Journal of Adolescence and Youth, 24(4), 511-520. https://doi.org/10.1080/02673843.2019.1570856

Ng, F., Trauer, T., Dodd, S., Callaly, T., Campbell, S., \& Berk, M. (2007). The validity of the 21 -item version of the Depression Anxiety Stress Scales as a routine clinical outcome measure. Acta Neuropsychiatrica, 19(5), 304-310. https://doi.org/10.1111/j.1601-5215.2007.00217.x

Norton, P. J. (2007). Depression Anxiety and Stress Scales (DASS-21): Psychometric analysis across four racial groups. Anxiety, Stress \& Coping, 20(3), 253-265. https://doi.org/10.1080/10615800701309279 
Oei, T. P. S., Sawang, S., Goh, Y. W., \& Mukhtar, F. (2013). Using the Depression Anxiety Stress Scale 21 (DASS-21) across cultures. In International Journal of Psychology (Vol. 48, Issue 6, pp. 10181029). Taylor \& Francis. https://doi.org/10.1080/00207594.2012.755535

Osman, A., Wong, J. L., Bagge, C. L., Freedenthal, S., Gutierrez, P. M., \& Lozano, G. (2012). The Depression Anxiety Stress Scales-21 (DASS-21): Further examination of dimensions, scale reliability, and correlates. Journal of Clinical Psychology, 68(12), 1322-1338. https://doi.org/10.1002/jclp.21908

Page, A. C., Hooke, G. R., \& Morrison, D. L. (2007). Psychometric properties of the Depression Anxiety Stress Scales (DASS) in depressed clinical samples. British Journal of Clinical Psychology, 46(3), 283-297. https://doi.org/10.1348/014466506X158996

Patias, N. D., Machado, W. D. L., Bandeira, D. R., \& Dell'Aglio, D. D. (2016). Depression Anxiety and Stress Scale (DASS-21) - Short Form: Adaptation and validation for Brazilian adolescents. Psico-USF, 21(3), 459-469. https://doi.org/10.1590/1413-82712016210302

Radloff, L. S. (1977). The CES-D Scale. Applied Psychological Measurement, 1(3), 385-401. https://doi.org/10.1177/014662167700100306

Randall, D., Thomas, M., Whiting, D., \& McGrath, A. (2017). Depression Anxiety Stress Scales (DASS-21): Factor structure in traumatic brain injury rehabilitation. Journal of Head Trauma Rehabilitation, 32(2), 134-144. https://doi.org/10.1097/HTR.0000000000000250

Reise, S. P. (2012). The rediscovery of bifactor measurement models. Multivariate Behavioral Research, 47(5), 667-696. https://doi.org/10.1080/00273171.2012.715555

Ronk, F. R., Korman, J. R., Hooke, G. R., \& Page, A. C. (2013). Assessing clinical significance of treatment outcomes using the DASS-21. Psychological Assessment, 25(4), 1103-1110. https://doi.org/10.1037/a0033100

Schnapp, J. E., O'Neal, D. N., \& Vaughn, A. A. (2020). Dyadic perceptions of depression and anxiety in romantic relationships. Journal of Social and Personal Relationships, 37(2), 432-449. https://doi.org/10.1177/0265407519867418

Schreiber, J. B., Nora, A., Stage, F. K., Barlow, E. A., \& King, J. (2006). Reporting structural equation modeling and confirmatory factor analysis results: A review. The Journal of Educational Research, 99(6), 323-338. https://doi.org/10.3200/JOER.99.6.323-338

Severino, G. A., \& Haynes, W. D. G. (2010). Development of an Italian version of the Depression Anxiety Stress Scales. Psychology, Health \& Medicine, 15(5), 607-621. https://doi.org/10.1080/13548506.2010.498889

Sinclair, S. J., Siefert, C. J., Slavin-Mulford, J. M., Stein, M. B., Renna, M., \& Blais, M. A. (2012). Psychometric evaluation and normative data for the Depression, Anxiety, and Stress Scales-21 (DASS-21) in a nonclinical sample of U.S. adults. Evaluation \& the Health Professions, 35(3), 259-279. https://doi.org/10.1177/0163278711424282

Spielberger, C. D., Goruch, R. L., \& Lushene, R. E. (1970). Manual for State Trait Anxiety Inventory (STAI YII). Consulting Psychologist Press.

Spitzer, R. L., Kroenke, K., Williams, J. B. W., \& Löwe, B. (2006). A brief measure for assessing generalized anxiety disorder. Archives of Internal Medicine, 166(10), 1092. https://doi.org/10.1001/archinte.166.10.1092

Tonsing, K. N. (2014). Psychometric properties and validation of Nepali version of the Depression Anxiety Stress Scales (DASS-21). Asian Journal of Psychiatry, 8, 63-66. https://doi.org/10.1016/j.ajp.2013.11.001 
Tran, T. D., Tran, T., \& Fisher, J. (2013). Validation of the depression anxiety stress scales (DASS) 21 as a screening instrument for depression and anxiety in a rural community-based cohort of northern Vietnamese women. BMC Psychiatry, 13(1), 24. https://doi.org/10.1186/1471-244X$13-24$

Tully, P. J., Zajac, I. T., \& Venning, A. J. (2009). The structure of Anxiety and Depression in a normative sample of younger and older Australian adolescents. Journal of Abnormal Child Psychology, 37(5), 717-726. https://doi.org/10.1007/s10802-009-9306-4

van de Schoot, R., Lugtig, P., \& Hox, J. (2012). A checklist for testing measurement invariance. European $\begin{array}{llll}\text { Journal of Developmental } & \text { Psychology, } & \text { 9(4), }\end{array}$ https://doi.org/10.1080/17405629.2012.686740

Vandenberg, R. J., \& Lance, C. E. (2000). A review and synthesis of the measurement invariance literature: Suggestions, practices, and recommendations for organizational research. Organizational Research Methods, 3(1), 4-70. https://doi.org/10.1177/109442810031002

Vignola, R. C. B., \& Tucci, A. M. (2014). Adaptation and validation of the Depression, Anxiety and Stress Scale (DASS) to Brazilian Portuguese. Journal of Affective Disorders, 155(1), 104-109. https://doi.org/10.1016/j.jad.2013.10.031

Wang, B., You, J., Lin, M. P., Xu, S., \& Leung, F. (2017). Developmental trajectories of nonsuicidal selfinjury in adolescence and intrapersonal/interpersonal risk factors. Journal of Research on Adolescence, 27(2), 392-406. https://doi.org/10.1111/jora.12273

Watson, D., Clark, L. A., Weber, K., Assenheimer, J. S., Strauss, M. E., \& McCormick, R. A. (1995). Testing a tripartite model: II. Exploring the symptom structure of anxiety and depression in student, adult, and patient samples. Journal of Abnormal Psychology, 104(1), 15-25. https://doi.org/10.1037/0021-843X.104.1.15

Xavier, S., João Martins, M., Pereira, A. T., Paula Amaral, A., João Soares, M., Roque, C., \& Macedo, A. (2017). Contribution for the Portuguese validation of the Depression, Anxiety and Stress Scales (DASS-21): Comparison between dimensional models in a sample of students. European Psychiatry, 41(S1), S416-S416. https://doi.org/10.1016/j.eurpsy.2017.01.365

Yıldırım, A., Boysan, M., \& Kefeli, M. C. (2018). Psychometric properties of the Turkish version of the Depression Anxiety Stress Scale-21 (DASS-21). British Journal of Guidance and Counselling, 46(5), 582-595. https://doi.org/10.1080/03069885.2018.1442558

Yohannes, A. M., Dryden, S., \& Hanania, N. A. (2019). Validity and responsiveness of the Depression Anxiety Stress Scales-21 (DASS-21) in COPD. Chest, 155(6), 1166-1177. https://doi.org/10.1016/j.chest.2018.12.010

Zanon, C., Brenner, R. E., Baptista, M. N., Vogel, D. L., Rubin, M., Al-Darmaki, F. R., Gonçalves, M., Heath, P. J., Liao, H. Y., Mackenzie, C. S., Topkaya, N., Wade, N. G., \& Zlati, A. (2020). Examining the dimensionality, reliability, and invariance of the Depression, Anxiety, and Stress Scale-21 (DASS-21) across eight countries. Assessment. https://doi.org/10.1177/1073191119887449

Zhang, B., Sun, T., Cao, M., \& Drasgow, F. (2020). Using bifactor models to examine the predictive validity of hierarchical constructs: Pros, cons, and solutions. Organizational Research Methods, 109442812091552. https://doi.org/10.1177/1094428120915522 